\section{Woodlouse diversity on some Clyde Estuary islands}

\author{
C.S. Boyle \& G.D. Ruxton ${ }^{1}$ \\ School of Biology, University of St. Andrews, St. \\ Andrews, Fife KY16 9TH \\ ${ }^{1}$ E-mail: gr41@st-andrews.ac.uk
}

Woodlice (Isopoda: Oniscidea) are ubiquitous in terrestrial habitats, and over 30 species are native or naturalised in the U.K. Throughout the summer of 2017 C.S.B. opportunistically searched extensively around the islands of Arran, Bute and (with the owner's permission) Pladda for woodlice.

At $432 \mathrm{~km}^{2}$ Arran is the largest island in the Firth of Clyde, with a resident human population of around 4,600 . Pladda is a very small $\left(0.11 \mathrm{~km}^{2}\right)$ island $1 \mathrm{~km}$ to the south of Arran. It is uninhabited but has a lighthouse built in 1790 and staffed since then until it was automated in 1990. Bute $\left(122 \mathrm{~km}^{2}\right)$ lies to the north of Arran, and is the most populous of the Firth of Clyde islands, with a resident human population of around 6,400 . It is only $300 \mathrm{~m}$ from the mainland at its nearest point.

Three woodlice species were present on all three islands (see Table 1). The common shiny woodlouse (Oniscus asellus) was found at 49 locations on Arran, eight on Bute and six on Pladda. The common rough woodlouse (Porcellio scaber) was found at 52, five and five locations respectively. Finally, the common sea slater (Ligia oceanica) was found at four, one and four locations respectively.

In addition, two other species were found on Arran: the common striped woodlouse (Philoscia muscorum) at four locations, and the common pill woodlouse (Armadillidium vulgare) at two locations. This last species was also found at two locations on Bute. No other species were found on Pladda.

Previously, Gregory (2016) reported the following species found at one location on Arran in 2010: the common rough woodlouse, the rosy woodlouse (Androniscus dentiger), the common pygmy woodlouse
(Trichoniscus pusillus agg.), and the ant woodlouse (Platyarthrus hoffmannseggii). The low overlap with this study speaks to the impressive diversity of woodlice within a small geographical area thanks to their variety of lifestyles and low dispersal ranges.

The common pill woodlouse was previously reported on Bute by Collis \& Collis (2008).

Previous surveys on Bute in 1999 and 2003 (Collis \& Collis 2004), did not find the common pill woodlouse but did report the other species we found plus the common pygmy woodlouse, rosy woodlouse, Haplophthalmus mengii (sensu lato), T. pygmaeus, and Cylisticus convexus. Had we surveyed in a more targeted fashion at a damper time of year, we would have expected to find some pygmy species: T. pusillus agg. and T. pygmaeus on at least the larger two islands, and perhaps $T$. saeroeensis, which has been found on the nearby mainland coast.

That tiny Pladda can support three (albeit common) species of woodlice speaks for their exceptional colonisation ability, often helped inadvertently by humans, and their population resilience once stabilised.

\section{REFERENCES}

Collis, G.M. \& Collis, D. (2004). Woodlice on the Scottish islands of Bute, Islay and Mull. Bulletin of the British Myriapod and Isopod Group 20, 20-24.

Collis, G.M. \& Collis, D. (2008). The pill woodlouse, Armadillidium vulgare, at one-time horticultural nursery sites on Bute. Transactions of the Buteshire Natural History Society 27, 87-88.

Gregory, S.J. (2016). Report of the BMIG field meeting at Claonaig, Kintyre, autumn 2010: woodlice and millipedes, including additional Scottish records of Chordeuma sylvestre C.L. Koch and Leptoiulus belgicus (Latzel). Bulletin of the British Myriapod and Isopod Group 29, 50-57.

\begin{tabular}{lccccc}
\hline & Oniscus asellus & Porcellio scaber & Ligia oceanica & \multicolumn{1}{c}{$\begin{array}{l}\text { Armadillidium } \\
\text { vulgare }\end{array}$} & $\begin{array}{l}\text { Philoscia } \\
\text { muscorum }\end{array}$ \\
\hline Bute & & & $\mathrm{X}$ & \\
Arran & $\mathrm{X}$ & $\mathrm{X}$ & $\mathrm{X}$ & $\mathrm{X}$ & $\mathrm{X}$ \\
Pladda & $\mathrm{X}$ & $\mathrm{X}$ & $\mathrm{X}$ & $\mathrm{X}$ & \\
\hline
\end{tabular}

Table 1: Summary of woodlouse species found on the three is lands in the Clyde Estuary during 2017 